\title{
Application of PCR-DGGE to analyse the yeast population dynamics in slurry reactors during degradation of polycyclic aromatic hydrocarbons in weathered oil
}

\author{
Abd El-Latif Hesham ',2, Sardar Khan', XinChun Liu', Yu Zhang', Zhenyu Wang' and Min Yang '* \\ I Research Centre for Eco-environmental Sciences, Chinese Academy of Sciences, PO Box 2871, Beijing 100085, People's Republic of China \\ ${ }^{2}$ Genetics Department, Faculty of Agriculture, Assiut University, Assiut, Egypt
}

* Correspondence to:

Min Yang, Research Centre for

Eco-environmental Sciences,

Chinese Academy of Sciences,

PO Box 287I, Beijing 100085,

People's Republic of China.

E-mail:

yangmin@mail.rcees.ac.cn
Received: 18 May 2006

Accepted: 5 July 2006

\begin{abstract}
Slurry-phase reactors have been used to investigate the biodegradation feasibility of polycyclic aromatic hydrocarbons (PAHs) in weathered crude oil, by mixed culture containing five PAHs-degrading yeast strains. Yeasts were isolated from the oily soil by enrichment culture, using phenanthrene as a sole carbon source, and identified based on the 26S ribosomal DNA (rDNA) sequence. Yeast strains belonged to the genera Candida, Pichia, Rhodotorula and Sporidiobolus. The experiment was carried out for a period of 6 weeks at room temperature with a solid:liquid ratio of $50 \% \mathrm{w} / \mathrm{w}$. The results showed that high removal efficiency was obtained for all PAHs, including low molecular weight (LMW) and high molecular weight (HMW) compounds (89.3-98.6\% and 66.3-89.4\% within 6 weeks, respectively). The higher removal efficiency for HMW-PAHs obtained in this work suggested that yeast strains mixture could play an important role to reclaim oil-contaminated sites. Denaturing gradient gel electrophoresis (DGGE) of polymerase chain reaction (PCR)-amplified 26S rRNA genes was used to follow the changes of yeast populations during the slurry reactor process. The results of DGGE indicated that Candida maltosa-like and Pichia guilliermondii were the dominant species but Rhodotorula dairenensis appeared as a weak band and Sporidiobolus salmonicolor and Pichia anomala disappeared during the study. Moreover, the results showed that all of the five strains, including the two belonging to the same genus, could be differentiated from each other in the DGGE profile. Sequences of yeast isolates reported in this study have been deposited in the GenBank database under Accession Nos DQ302753, DQ303392, DQ303393, DQ350841 and DQ432635. Copyright $\odot 2006$ John Wiley \& Sons, Ltd.
\end{abstract}

Keywords: degradation; PAHs; slurry reactor; isolation; identification; 26S rRNA gene; PCR-DGGE

\section{Introduction}

Recently, oil-contaminated soil has become a focus point for research and there have been many studies on the source, fate and remediation of oilcontaminated soil (Barakat et al., 2002; Meysami and Baheri, 2003; Trindade et al., 2005). Oil is a complex mixture of hydrocarbons, basically composed of aliphatic and aromatic hydrocarbons. The aromatic fractions, especially polycyclic aromatic hydrocarbons (PAHs), are compounds of intense public concern, owing to their persistence in the environment and potential deleterious effects on human health. Although indigenous microorganisms could utilize crude oil as a source of energy and break it down into non-toxic compounds (Atlas, 1981; Cerniglia, 1992), they could not degrade the high molecular weight 
PAHs (HMW-PAHs), which are more harmful than the lower molecular weight PAHs in weathered oil-contaminated soils (Trindade et al., 2005).

Numerous efforts have been dedicated to the search for proper remediation technologies to remove as many contaminants as possible from the environment. The most widely used technologies for the remediation of oil- or PAH-contaminated soils and sediments include land farming, bioventing, air sparging and the bioslurry reactor (US EPA/540/290/016, 1990; Wilson et al., 1993; Katsivela et al., 2005). A very high removal efficiency for some PAHs can be obtained in slurry phase reactors (EPA/540/A5-91/009, 1993; Woodhull and Jerger, 1995; Saponaro et al., 2002), where contact between microorganisms, contaminants, nutrients and oxygen is more intimate than with solid-phase systems. Various recent studies have investigated the possibility of bioremediation of PAH-polluted soil with PAH-degrading bacterial consortia or pure strains, and enhanced PAH degradation in soil slurries and soil microcosms has indeed often been observed (Johnsen et al., 2005). Although yeast has been found to be active in oil degradation (Palittapongarnpim et al., 1998), information regarding yeast degradation of PAHs has been minimal. The ability of yeast to degrade HMW PAHs has therefore become of interest.

The objective of this study was to investigate the feasibility of biodegradation of PAHs in synthetic weathered crude oil by a PAH-degrading yeast strain mixture inoculated into slurry reactors. PAH-degrading yeast strains were isolated from an oilfield soil site contaminated with oil and identified using a molecular technique. In order to trace the behaviour of the inoculated yeast strains in the slurry reactor system, the PCR-DGGE technique was applied.

Genetic fingerprinting techniques are able to provide a profile representing the genetic diversity of a microbial community from specific environment. The PCR-DGGE analysis represents a powerful tool to study the structure of microbial communities in environmental samples without cultivation and to determine the community dynamics in response to environmental variations. Although PCR-DGGE has been applied to the study of bacterial community structure associated with bioremediation of oil(PAH)-polluted soil (Macnaughton et al., 1999; Ringelberg et al., 2001; Zucchi et al., 2003; Leys et al., 2004; Vinas et al., 2005), the method using $26 \mathrm{~S}$ ribosomal RNA (26S rRNA) gene has only been applied to the investigation of yeast populations in environmental samples such as milk (Cocolin et al., 2002) and sourdough (Meroth et al., 2003) and during coffee (Masoud et al., 2004), wine (Cocolin et al., 2000; Cocolin and Mills, 2003; Prakitchaiwattana et al., 2004) and cocoa fermentations (Nielsen et al., 2005). This was therefore the first time the PCR-DGGE technique was used to investigate yeast population dynamics in a slurry reactor system.

\section{Materials and methods}

\section{Enrichment and isolation}

Oil-contaminated soil samples were taken from Jidong Oilfield in Hebei Province, China. A soil enrichment technique was used for the isolation of PAH-degrading yeasts. Briefly, about $1 \mathrm{~g}$ soil was suspended in $10 \mathrm{ml}$ sterile water and added to a mineral basal salts (MBS) medium containing, per litre distilled water, $1000 \mathrm{mg}\left(\mathrm{NH}_{4}\right)_{2} \mathrm{SO}_{4}, 800 \mathrm{mg}$ $\mathrm{K}_{2} \mathrm{HPO}_{4}, 200 \mathrm{mg} \mathrm{KH}{ }_{2} \mathrm{PO}_{4}, 200 \mathrm{mg} \mathrm{MgSO}{ }_{4} 7 \mathrm{H}_{2} \mathrm{O}$, $100 \mathrm{mg} \mathrm{CaCl} 22 \mathrm{H}_{2} \mathrm{O}, 5 \mathrm{mg} \mathrm{FeSO}{ }_{4} 7 \mathrm{H}_{2} \mathrm{O}$, pH 5-6, and $1 \mathrm{ml}$ vitamin solution sterilized by filtration, supplemented with $0.2 \%$ phenanthrene at $27^{\circ} \mathrm{C}$ at 150 r.p.m. for 10 days. When growth was visible, enrichment was continued by serially subculturing several times in the same medium, using a $10 \%$ inoculum from the previous culture. Yeast strains were isolated from MBS agar plates coated with phenanthrene as the sole carbon source (Romero et al., 1998).

\section{DNA extraction}

Two methods for the extraction of DNA were used. The first, for extracting DNA from pure cultures, was performed according to procedures described by Harju et al. (2004). The second, for extracting total DNA from soil, was performed by modified methods of Harju et al. (2004). Briefly, soil samples $(0.5 \mathrm{~g})$ were washed twice with $1 \mathrm{ml}$ PBS buffer (containing, per litre distilled water, $8 \mathrm{~g} \mathrm{NaCl}, 0.2 \mathrm{~g} \mathrm{KCl}, 0.24 \mathrm{~g} \quad \mathrm{KH}_{2} \mathrm{PO}_{4}, 1.44 \mathrm{~g}$ $\left.\mathrm{Na}_{2} \mathrm{PO}_{4}, \mathrm{pH} 7.4\right)$ and centrifuged at 80000 r.p.m. for $5 \mathrm{~min}$. The pellets were resuspended in $1 \mathrm{ml}$ lysis buffer (2\% Triton X-100, 1\% SDS, $100 \mathrm{~mm}$ $\mathrm{NaCl}, 10 \mathrm{~mm}$ Tris-HCl, pH 8.0, 1 mM EDTA, pH 8.0) and $0.3 \mathrm{~g}$ glass beads. The tubes were placed 
in a $-80^{\circ} \mathrm{C}$ freezer for $5 \mathrm{~min}$, and then immersed in a $95^{\circ} \mathrm{C}$ waterbath for $3 \mathrm{~min}$ to thaw quickly. This step was repeated once, and the tubes were vortexed vigorously for $60 \mathrm{~s}$. Phenol: chloroform $(1: 1,1 \mathrm{ml})$ was added and the tubes were vortexed for $2 \mathrm{~min}$ and then centrifuged for $3 \mathrm{~min}$ at room temperature at $20000 \times g$. The aqueous layer was transferred to a tube containing $1000 \mu \mathrm{l}$ ice-cold $100 \%$ ethanol for $5 \mathrm{~min}$ at room temperature and then centrifuged for $5 \mathrm{~min}$ at room temperature at $20000 \times g$. Supernatants were discarded and DNA pellets were washed with $0.5 \mathrm{ml} 70 \%$ ethanol, followed by vacuum drying for $20 \mathrm{~min}$ at room temperature, and then DNA was resuspended in $80 \mu \mathrm{l}$ TE buffer.

\section{Identification of PAH-degrading yeasts by $26 \mathrm{~S}$ rDNA sequences}

DNA was isolated and fragments containing the D1/D2 region of about $600-650 \mathrm{bp}$ at the $5^{\prime}$ end of the 26S rDNA were amplified, using primers NL-1 and NL-4 (Kurtzman and Robnett, 1998). PCR was performed in a final volume of $50 \mu \mathrm{L}$ containing $10 \mathrm{~mm}$ Tris- $\mathrm{HCl}(\mathrm{pH} 8.3), 50 \mathrm{~mm} \mathrm{KCl}, 1.5 \mathrm{~mm}$ $\mathrm{MgCl}_{2}$, each dNTP at a concentration of $0.2 \mathrm{~mm}$, 1.25 IU Taq polymerase (Takara, Dalian, China), each primer at a concentration of $0.2 \mathrm{~mm}$ and $1 \mu \mathrm{l}$ DNA template. The amplification was carried out by polymerase chain reaction (PCR) under the following conditions: initial denaturation at $95^{\circ} \mathrm{C}$ for $5 \mathrm{~min}$, followed by 36 cycles at $94^{\circ} \mathrm{C}$ for $2 \mathrm{~min}$, $52{ }^{\circ} \mathrm{C}$ for $1 \mathrm{~min}, 72^{\circ} \mathrm{C}$ for $2 \mathrm{~min}$; final extension at $72{ }^{\circ} \mathrm{C}$ for $7 \mathrm{~min}$, holding at $4{ }^{\circ} \mathrm{C}$. The amplified products were then purified and sequenced (Shanghai GeneCor Biotechnologies Co., Ltd). The obtained sequence data were compared with those of all known yeast species, available at the GenBank database.

\section{Soil characteristics}

Clean soil sample $(0-20 \mathrm{~cm})$ was collected from a garden in Beijing. After transportation to the laboratory, the soil was air-dried, ground and sieved through a $2 \mathrm{~mm}$ mesh. Selected physicochemical properties of the sample were measured according to standard procedures (Table 3 ). Soil $\mathrm{pH}$ was measured by $\mathrm{H}_{2} \mathrm{O}(1: 2.5$ ratio $)$ and by $\mathrm{CaCl}_{2}(1: 10$ ratio) (Kalra, 1995). The contents of extractable cations including $\mathrm{K}, \mathrm{Na}, \mathrm{Mg}$ and $\mathrm{Ca}$ were measured using inductively coupled plasma optical emission spectrometry (ICP-OES), using an OPTIMA-2000 (Perkin-Elmer, USA; McKeague, 1981). The initial available $\left(50 \mathrm{~mm} \mathrm{CaCl}_{2}\right) \mathrm{Cd}, \mathrm{Ni}, \mathrm{Cu}$ and $\mathrm{Pb}$ concentrations were below the detection limit. Organic $\mathrm{C}$ was measured by the modified Walkley-Black method (Houba et al., 1989).

\section{Biodegradation experiment}

A bench-scale slurry reactor experiment was conducted using glass beakers in the laboratory control environment. Sterile uncontaminated soil (autoclaved at $121^{\circ} \mathrm{C}$ for $20 \mathrm{~min}$ ) was mixed with synthetic weathered crude oil treated at $230{ }^{\circ} \mathrm{C}$ according to Maki et al. (2001). In the slurry reactors, a 50\% solid: liquid w/w ratio was obtained by using dry sieved soil $(<2 \mathrm{~mm})$ and deionized water. Macronutrients, including $\mathrm{NH}_{4} \mathrm{Cl}(6.39 \mathrm{~g})$, $\mathrm{K}_{2} \mathrm{HPO}_{4}(0.33 \mathrm{~g})$ and $\mathrm{KH}_{2} \mathrm{PO}_{4}(0.25 \mathrm{~g})$ were introduced in reactors to keep a w/w balance between $\mathrm{C}: \mathrm{N}: \mathrm{P}$ ratios $(100: 5: 1)$. A mixed culture containing five PAH-degrading yeast strains was inoculated in the slurry reactors. In order to maintain aerobic conditions in the reactors, aeration was provided by a magnetic stirrer. Sterile controls were also used to quantify the abiotic losses of PAHs. The experiment was carried out for a period of 6 weeks at room temperature. Water losses due to evaporation were compensated for by daily addition of deionized water on a weight basis. Samples were taken for an initial concentration determination $3 \mathrm{~h}$ after the slurry reactor systems had been amended with weathered crude oil and yeast mixtures. Further samples were taken on a weekly basis. All results of biodegradation were obtained in reference to sterile controls: $R 1-R 2 / R 1 \times 100$ (where $R 1$ is the residual PAH concentration in the control, while $R 2$ is the residual PAH concentration in the degradation beaker).

\section{$\mathrm{PAH}$ extraction and analysis conditions}

The PAHs were extracted by the method as used by Wu et al. (2005) with slight modifications. Briefly, the whole beaker soil (Villemur et al., 2000) was used to extract PAHs by the Soxhlet extraction method with $200 \mathrm{ml}$ dichloromethane (DCM) for $24 \mathrm{~h}$. After filtration, the extract was evaporated to approximately $1 \mathrm{ml}$ at $35^{\circ} \mathrm{C}$, using a rotary evaporator. Silica chromatography columns were prepared with silica gel and $\mathrm{Al}_{2} \mathrm{O}_{3}$ and capped with $\mathrm{Na}_{2} \mathrm{SO}_{4}$ (activated before use at $180^{\circ} \mathrm{C}, 250^{\circ} \mathrm{C}$ 
and $450{ }^{\circ} \mathrm{C}$ for at least $12 \mathrm{~h}$, respectively) and then washed with hexane. The concentrated extracts were loaded onto columns to separate the PAHs from other polar interfering compounds. These columns were eluted with hexane and DCM (15: 70 $\mathrm{ml})$; the eluted fractions were again evaporated to $1 \mathrm{ml}$ using a rotary evaporator and transferred to a Kuderna-Danish concentrator and rinsed with $10 \mathrm{ml} n$-hexane. The extracts were dried to $1 \mathrm{ml}$ under a gentle nitrogen flow and transferred to a vial capped with a Teflon-lined septum for GC-MS analysis. The concentrations of PAHs in the extracts were determined using an Agilent 6890 gas chromatograph equipped with a 5973 mass selective detector under the selected ion monitoring mode (SIM). An HP-5 silica fused capillary column (60 $\mathrm{m} \times 0.25 \mathrm{~mm}$ i.d., $0.25 \mu \mathrm{m}$ film thickness) was used, with helium as the carrier gas at a constant flow rate of $1 \mathrm{ml} / \mathrm{min}$. The GC oven temperature was programmed from $50^{\circ} \mathrm{C}(2 \mathrm{~min})$ to $200^{\circ} \mathrm{C}(2 \mathrm{~min})$ at $10^{\circ} \mathrm{C} / \mathrm{min}$, then to $290^{\circ} \mathrm{C}$ at $20^{\circ} \mathrm{C} / \mathrm{min}$ and held for $8 \mathrm{~min}$. The injector and detector temperatures were $280^{\circ} \mathrm{C}$ and $290^{\circ} \mathrm{C}$, respectively. Mass spectra were acquired at the electron ionization (EI) mode with an electron multiplier voltage of $1906 \mathrm{eV}$. Quantification was performed using the five-point calibration curve for individual components. The detection limit for all PAHs was $0.001-0.01 \mathrm{mg} / \mathrm{l}$.

\section{Recovery and quality control}

Clean soil samples were spiked with 16 known PAHs $(1-2 \mu \mathrm{g} / \mathrm{g})$. The recovery and reproducibility of the extraction method was satisfactory, ranging from $91.3 \pm 5.6 \%$ to $95.3 \pm 3.9 \%$.

\section{PCR-DGGE and primers}

The D1/D2 domain of the 26S rRNA gene was amplified by a two-step, nested PCR. The first PCR was conducted with the forward primer, NL1 (5'-GCA TAT CAA TAA GCG GAG GAA AAG$\left.3^{\prime}\right)$, and reverse primer, NL4 (5'-GGT CCG TGT TTC AAG ACG G-3'). PCR was performed in a final volume of $50 \mu$ l containing $10 \mathrm{~mm}$ Tris $-\mathrm{HCl}$ (pH 8.3), $50 \mathrm{~mm} \mathrm{KCl,} 1.5 \mathrm{~mm} \mathrm{MgCl}_{2}$, each dNTP at a concentration of $0.2 \mathrm{~mm}, 1.25 \mathrm{IU}$ Taq polymerase, each primer at a concentration of $0.2 \mathrm{mM}$, and $2 \mu \mathrm{l}$ DNA template. PCR was run for 36 cycles with annealing at $52^{\circ} \mathrm{C}$, extension at $72^{\circ} \mathrm{C}$ for
$2 \mathrm{~min}$, and denaturation at $94^{\circ} \mathrm{C}$ for 1 min (Kurtzman and Robnett, 1998). The amplicon (approximately $600 \mathrm{bp}$ ) from the first PCR was diluted and further amplified with a second PCR, using the GC-clamp primer NL1 (5'-CGC CCG CCG CGC GCG GCG GGC GGG GCG GGG GCC ATA TCA ATA AGC GGA GGA AAA G-3'; GCclamp underlined) and reverse primer LS2 (5'-ATT CCC AAA CAA CTC GAC TC-3') (Cocolin et al., 2000). The conditions of this reaction were the same as described above. The PCR was run with an initial step at $95^{\circ} \mathrm{C}$ for $5 \mathrm{~min}$, and 30 cycles of denaturation at $95^{\circ} \mathrm{C}$ for $1 \mathrm{~min}$, annealing at $52^{\circ} \mathrm{C}$ for $2 \mathrm{~min}$, extension at $72{ }^{\circ} \mathrm{C}$ for $2 \mathrm{~min}$, with a final extension at $72^{\circ} \mathrm{C}$ for $7 \mathrm{~min}$. The amplified mixture $(5 \mathrm{ml})$ was analysed in a $1.5 \% 0.5 \times \mathrm{TBE}$ agarose gel electrophoresis. The gel was stained with $0.5 \mathrm{mg} / \mathrm{ml}$ ethidium bromide, visualized under UV light and photographed.

\section{DGGE analysis}

The GC clamp products were separated according to their sequences, using DGGE, with a Bio-Rad Dcode System (Bio-Rad, USA). The PCR product was loaded on $0.8 \mathrm{~mm}$ thick polyacrylamide gel (8\% w/v acrylamide : bisacrylamide $37.5: 1)$ using a denaturing gradient from $30 \%$ to $50 \%$ of urea and formamide (100\% corresponds to $7 \mathrm{~m}$ urea and $40 \%$ $\mathrm{w} / \mathrm{v}$ formamide), being increased in the direction of the electrophoresis run. The electrophoresis was performed under a constant voltage of $120 \mathrm{~V}$ for $6 \mathrm{~h}$ and a constant temperature of $60^{\circ} \mathrm{C}$. After the run, the gels were stained for $20 \mathrm{~min}$ in $1 \times$ TAE containing $0.5 \mathrm{mg} / \mathrm{ml}$ ethidium bromide and destained with distilled water, then photographed with UV transillumination.

\section{Results and discussion}

\section{Enrichment and isolation}

A series of pure yeast strains were isolated from the soil sample and their ability to grow on agar plates coated with phenanthrene, chrysene, or benzo(a)pyrene as the sole carbon source was investigated (data not shown). Five of the bestgrowing isolated yeast strains were selected for the slurry reactor system and identified by $26 \mathrm{~S}$ rDNA sequence. 
Table I. Identification of PAH-degrading yeast strains

\begin{tabular}{llc}
\hline $\begin{array}{l}\text { Strain } \\
\text { number }\end{array}$ & \multicolumn{1}{c}{$\begin{array}{c}\text { Identification and } \\
\text { GenBank Accession No. }\end{array}$} & $\begin{array}{c}\text { Identity } \\
\text { origin (\%) }\end{array}$ \\
\hline $\mathrm{AHI}$ & Candida maltosa-like DQ302753 & 99 \\
$\mathrm{AH} 2$ & Pichia anomala DQ432635 & 100 \\
$\mathrm{AH} 3$ & Sporidiobolus salmonicolor DQ303392 & 99 \\
$\mathrm{AH} 4$ & Pichia guilliermondii DQ303393 & 100 \\
$\mathrm{AH} 5$ & Rhodotorula dairenensis DQ35084I & 100 \\
\hline
\end{tabular}

\section{Identification and differentiation of $\mathrm{PAH}$-degrading yeasts}

The sequencing results of the D1/D2 of the large subunit 26S rDNA were submitted to the GenBank database. The results obtained from the yeast identification by the sequencing approach and their Accession Nos are described in Table 1. A variety of yeast species were differentiated by analysis of partial sequences of large subunit rDNA encompassing the D1 and D2 expansion domains (Kurtzman and Robnett, 1998). When the isolated strains were subjected to DGGE analysis, following PCR using the primers NL1GC/LS2, a good differentiation was obtained, as shown in Figure 1. It is clear that all five strains, including the two belonging to the same genus, could be differentiated from each other in the DGGE profile. These results are in agreement with results obtained by Cocolin et al. (2002) and Prakitchaiwattana et al. (2004). DGGE analysis was therefore used for following population changes during biodegradation of the weathered oil.

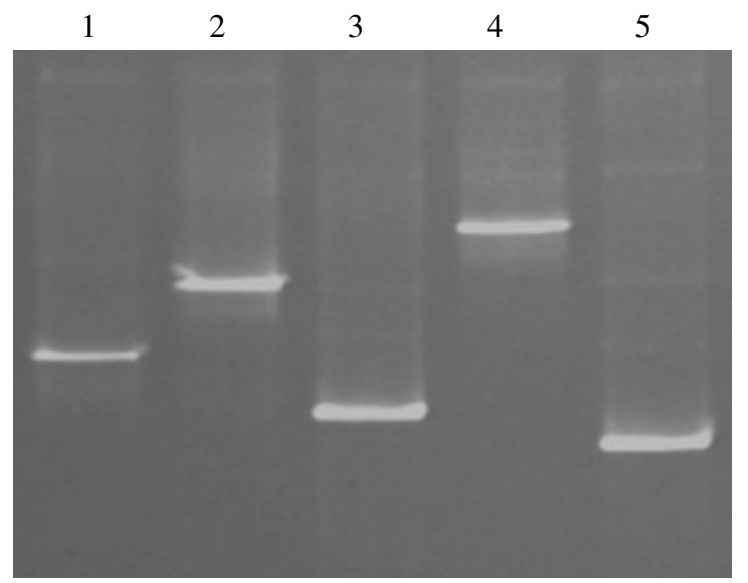

Figure I. DGGE profiles of amplified 26S rRNA DI/D2 regions obtained from different yeast strains isolated from oily soil. Lane I, Candida maltosa-like (AHI); lane 2, Pichia guilliermondii (AH4); lane 3, Rhodotorula dairenensis (AH5); lane 4, Pichia anomala ( $\mathrm{AH} 2)$; lane 5, Sporidiobolus salmonicolor $(\mathrm{AH} 3)$

\section{PAHs degradation}

The aliphatic hydrocarbons present in weathered oil were not considered in this study because of their easy degradability (Zinjarde and Pant, 2002). The initial concentrations, residual and degradation ratios of all of the PAHs are described in Table 2, and the degradation processes of LMW-PAHs and HMW-PAHs by the yeast mixture are shown in Figure 2(A,B) and Figure $3(\mathrm{~A}-\mathrm{D})$, respectively. The data indicate that all of the PAHs in the weathered oil were removed significantly, although

Table 2. Calculated mass balance of PAHs in slurry experiments

\begin{tabular}{lcccc}
\hline PAHs & $\begin{array}{c}\text { No. of } \\
\text { rings }\end{array}$ & $\begin{array}{c}\text { Initial concentration } \\
\text { (mg/kg) }\end{array}$ & $\begin{array}{c}\text { Remaining } \\
\text { (mg/kg) }\end{array}$ & $\begin{array}{c}\text { Degradation } \\
\text { (\%) }\end{array}$ \\
\hline Naphthalene & 2 & 0.69 & 0.07 & 89 \\
Acenaphthylene & 3 & 0.15 & 0.01 & 95 \\
Acenaphthene & 3 & 0.47 & 0.01 & 98 \\
Fluorene & 3 & 1.89 & 0.17 & 91 \\
Phenanthrene & 3 & 1.89 & 0.05 & 97 \\
Anthracene & 3 & 2.63 & 0.18 & 93 \\
Fluoranthene & 4 & 1.62 & 0.17 & 89 \\
Pyrene & 4 & 1.96 & 0.49 & 75 \\
Chrysene & 4 & 4.05 & 1.36 & 66 \\
Benzo(b)fluoranthene & 5 & 2.12 & 0.43 & 79 \\
Benzo(k)fluoranthene & 5 & 0.63 & 0.12 & 81 \\
Benzo(a)pyrene & 5 & 1.99 & 0.46 & 76 \\
Dibenzo(a,h)anthracene & 5 & 4.19 & 0.68 & 83 \\
Perylene & 5 & 6.03 & 1.81 & 70 \\
Indeno(I,2,3-cd)pyrene & 6 & 2.53 & 0.39 & 84 \\
Benzo(g,h,i)perylene & 6 & 2.17 & 0.47 & 78 \\
\hline
\end{tabular}


Table 3. Initial physicochemical properties of uncontaminated soil used for slurry reactors

\begin{tabular}{lc}
\hline Parameters & Values \\
\hline $\mathrm{pH}($ water $)$ & 8.12 \\
$\mathrm{pH}\left(\mathrm{CaCl}_{2}\right)$ & 7.68 \\
Particles sizes & \\
$\quad$ Sand & $46.80 \%$ \\
$\quad$ Silt & $39.71 \%$ \\
$\quad$ Clay & $13.49 \%$ \\
$\mathrm{~K}$ & $0.98 \mathrm{mg} / \mathrm{kg}$ \\
$\mathrm{Na}$ & $12.01 \mathrm{mg} / \mathrm{kg}$ \\
$\mathrm{Mg}$ & $210.54 \mathrm{mg} / \mathrm{kg}$ \\
$\mathrm{Ca}$ & $164.82 \mathrm{mg} / \mathrm{kg}$ \\
Organic matter & $1.02 \%$ \\
\hline
\end{tabular}

different individual PAHs demonstrated different degradation patterns. The removal efficiency for the LMW-PAHs was 89.3-98.6\% and that for the HMW-PAHs was 66.3-89.4\% after degradation for 6 weeks. According to the study conducted by Saponaro et al. (2002) using bacteria, the PAH removal efficiency was in the range $65-90 \%$ in slurry reactors, which also supported our results.

It is interesting that the five-ring PAHs, including benzo(b)fluoranthene, benzo(k)fluoranthene, benzo(a)pyrene, perylene and dibenzo(a,h)anthracene, and the six-ring PAHs, including indeno(1,2,3cd)pyrene and benzo(g,h,i)perylene, were removed

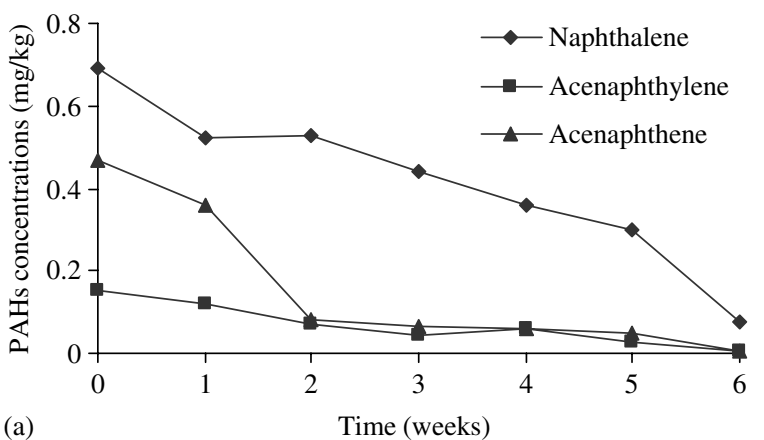

(a) Time (weeks)

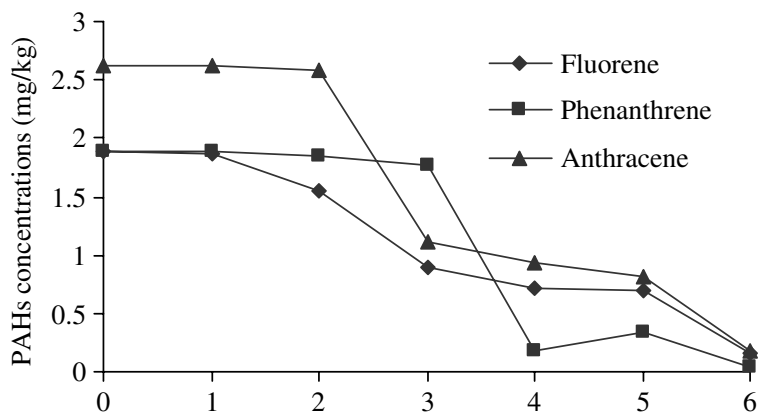

(b)

Time (weeks)

Figure 2. Biodegradation of LMW-PAHs in slurry reactors: (a) naphthalene, acenaphthylene and acenaphthene; (b) fluorene, phenanthrene and anthracene

with a relatively high efficiency $(70.1-84.2 \%)$. Previous studies demonstrated that the HMW-PAHs

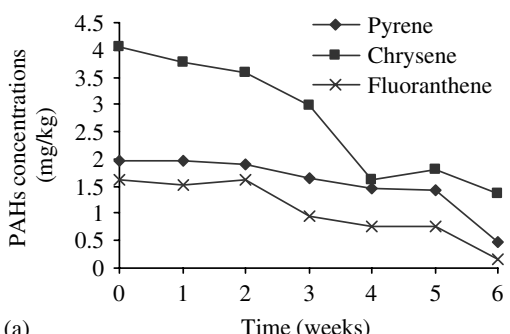

(a)

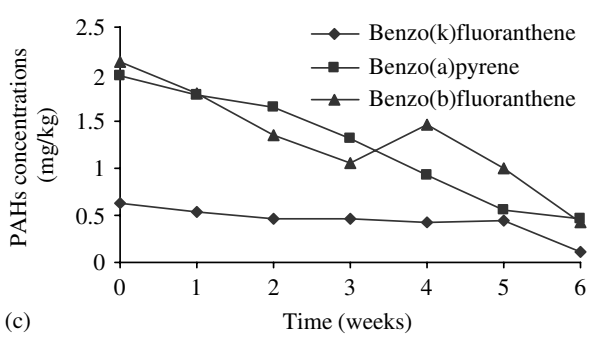

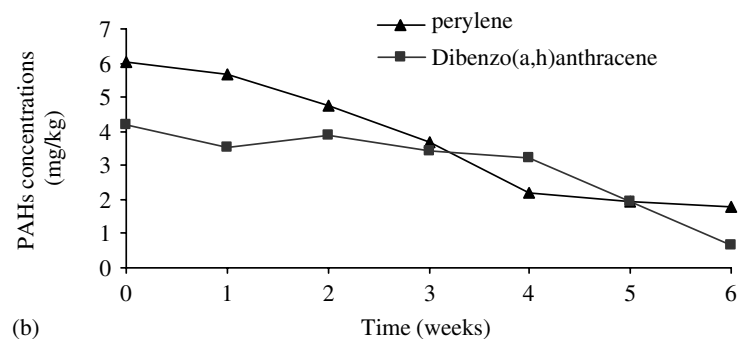

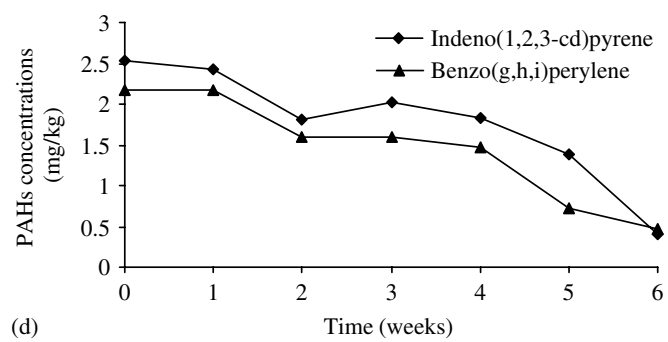

Figure 3. Biodegradation of HMW-PAHs in slurry reactors: (a) fluoranthene, pyrene and chrysene (four rings); (b) dibenzo(a,h)anthracene and perylene (five rings); (c) benzo(b)fluoranthene benzo(k)fluoranthene and benzo(a)pyrene (five rings); (d) indeno( $\mathrm{l}, 2,3-\mathrm{cd})$ pyrene and benzo(g,h,i)perylene (six rings) 
could not be utilized as carbon sources for yeasts such as Saccharomyces cerevisiae, Debaromyces hansenii, Candida lipolytica, Candida albicans, Candida guilliermondii, Candida maltosa and Pichia anomala (Cerniglia and Crow, 1981; McGillivray and Sharis, 1993; Zinjarde and Pant, 2002; Pan et al., 2004). The efficient removal of these compounds should be achieved through co-metabolism by the mixed yeasts, using the LMW-PAHs and aliphatic hydrocarbons as carbon sources. Hesham et al. (2006) found that benzo(a)pyrene (five rings) was decomposed by the yeast through co-metabolism only. This is the first report that the six-ring PAHs can be decomposed by a yeast mixture under co-metabolism. This study may encourage the use of mixed yeast consortia to reclaim oil-contaminated sites.

\section{Changes of yeast community structure}

Figure 4 shows DGGE profiles of 26S rRNA gene fragments of soil sampled from the slurry reactors at time 0,2 weeks, 4 weeks and 6 weeks during biodegradation, together with the yeast isolates as the control. All of the five yeast strains could be clearly identified at time zero. Sporidiobolus salmonicolor (band 5) disappeared after 2 weeks' treatment, and then Pichia anomala (band 4) disappeared. Rhodotorula dairenensis appeared as a weak band (band 3) within 4-6 weeks. Only
Candida maltosa-like (band 1) and Pichia guilliermondii (band 2) remained in the system as the bright band at the end of the experiment, suggesting that these two species might have a more important role during PAH degradation than the other species. It is clear that the DGGE technique could be effectively used to follow the changes of yeast populations during biodegradation of weathered crude oil (PAHs).

PCR-DGGE has been applied successfully to the study of bacterial community structure associated with bioremediation of different kinds of environmental pollutants, especially oil(PAH)-polluted soil (Macnaughton et al., 1999; Ringelberg et al., 2001; Zucchi et al., 2003; Leys et al., 2004; Vinas et al., 2005). The method using 26S rRNA gene has only been applied to investigate yeast populations in milk (Cocolin et al., 2002), sourdough (Meroth et al., 2003) and during coffee (Masoud et al., 2004), wine (Cocolin et al., 2000; Cocolin and Mills, 2003; Prakitchaiwattana et al., 2004) and cocoa fermentations (Nielsen et al., 2005). This study demonstrated that the DGGE technique could be effectively used to examine changes in yeasts.

In summary, slurry reactor systems inoculated with a yeast mixture removed all of the 16 PAHs contained in the weathered crude oil with high efficiency. Five- and six-ring PAHs could be effectively removed through co-metabolism. DGGE could differentiate different species from the same

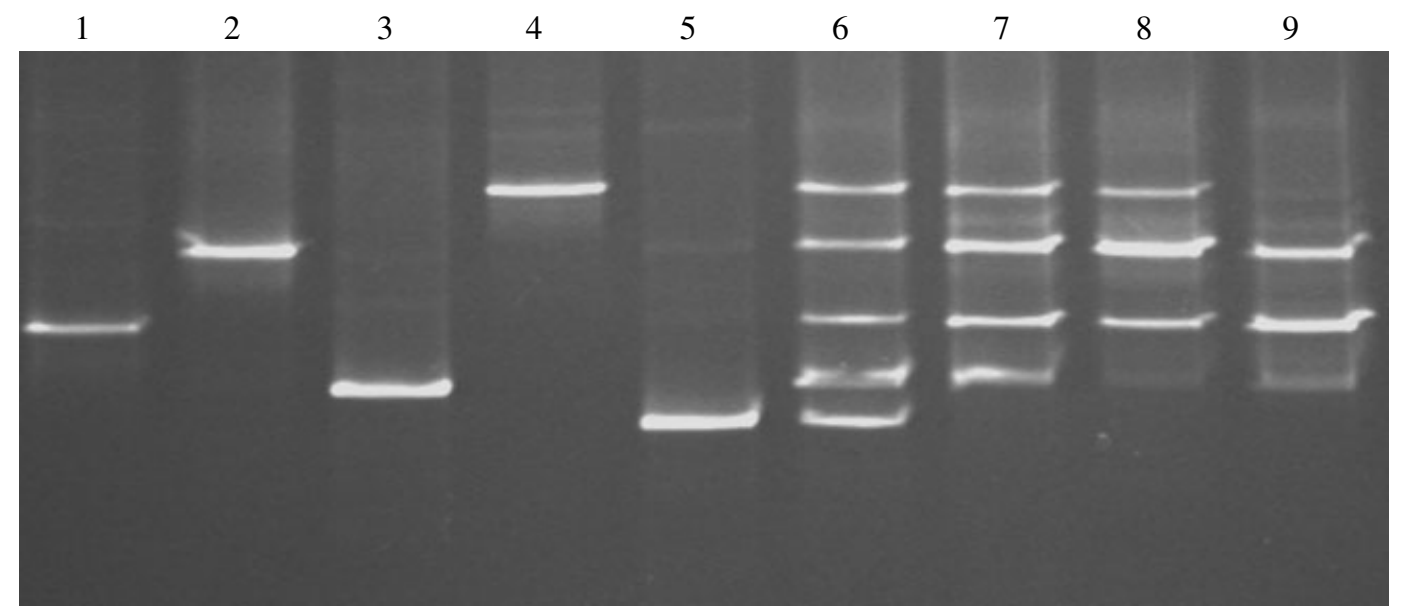

Figure 4. DGGE profiles of the PCR products obtained from the DNA extracted directly from slurry reactors and yeast isolates: Lane 6, 0 time; lane 7, 2 weeks; lane 8, 4 weeks; lane 9, 6 weeks. Lanes I-5 for yeast isolates, i.e. Candida maltosa-like, strain AHI (lane I); Pichia guilliermondii, strain AH4 (lane 2); Rhodotorula dairenensis, strain AH5 (lane 3); Pichia anomala, strain $\mathrm{AH} 2$ (lane 4); Sporidiobolus salmonicolor, strain $\mathrm{AH} 3$ (lane 5) 
genus, and was successfully used for the tracing of yeast population changes during biodegradation. Candida maltosa-like and Pichia guilliermondii were shown to be the predominant yeasts over the whole 6 week treatment.

\section{Acknowledgements}

This study was supported by grants from the National Natural Science Foundation of China (Nos 20337020 and 50525824) and the National Basic Research Program of China (No. 2003CB415006).

\section{References}

Atlas RM. 1981. Microbial degradation of petroleum hydrocarbons: an environmental perspective. Microbiol Rev 45: 180-209.

Barakat AO, Qian Y, Kim M, Kemmicutt MC. 2002. Compositional changes of aromatic steroid hydrocarbons in naturally wathered oil residues in th Egyptian western desert. Environ Forens 3: 219-225.

Cerniglia CE, Crow SA. 1981. Metabolism of aromatic hydr carbons by yeasts. Arch Microbiol 129: 9-13.

Cerniglia CE. 1992. Biodegradation of polycyclic aromatic hydrocarbons. Biodegradation 3: 351-368.

Cocolin L, Aggio D, Manzano M, Cantoni C, Comi G. 2002. An application of PCR-DGGE analysis to profile the yeast population in raw milk. Int Dairy J 12: 407-411.

Cocolin L, Bisson LF, Mills DA. 2000. Direct profiling of the yeast dynamics in wine fermentations. FEMS Microbiol Lett 189: $81-87$.

Cocolin L, Mills DA. 2003. Wine yeast inhibition by sulfu dioxide: a comparison of culture-dependent and culture independent methods. Am J Enol Viticult 54: 125-130.

EPA/540/290/016. 1990. Engineering bulletin: slurry biodegradation. Centre for Environmental Research, US EPA: Cincinnati, $\mathrm{OH}$, USA.

EPA/540/A5-91/009. 1993. Pilot scale demonstration of a slurry phase biological reactor for creosote-contaminated soil. Application Analysis Report. Risk Reduction Engineering Laboratory, Office of Research and Development, US EPA: Cincinnati, OH, USA.

Harju S, Fedosyuk H, Peterson KR. 2004. Rapid isolation of yeast genomic DNA: bust n' grab. BMC Biotechnol 4: 8 .

Hesham A, Wang Z, Zhang Y, et al. 2006. Isolation and identification of a yeast strain capable of degrading four and five ring aromatic hydrocarbons. Ann Microbiol 56(2): 109-112.

Houba VJG, Van der Lee JJ, Novozamsky I. 1989. In Soil and Plants Analysis, part 5, Waling I (ed.). Wageningen Agricultural University: Wageningen, The Netherlands.

Johnsen AR, Wick LY, Harms H. 2005. Principles of microbial PAH degradation in soil. Environ Pollut 133: 71-84.

Juhasz AL, Naidu R. 2000. Bioremediation of high molecular weight polycyclic aromatic hydrocarbons: a review of the microbial degradation of benzo[a]pyrene. Intern Biodeterior Biodegrad 45: 57-88.

Kalra Y. 1995. Determination of $\mathrm{pH}$ of soils by different methods: collaborative study. J AOAC Int 78: $310-320$.
Katsivela E, Moore ERB, Maroukli D, et al. 2005. Bacterial community dynamics during in situ bioremediation of petroleum waste sludge in landfarming sites. Biodegradation 16: 169-180.

Kurtzman CP, Robnett CJ. 1998. Identification and phylogeny of ascomycetous yeasts from analysis of nuclear large subunit (26S) ribosomal DNA partial sequences. Antonie van Leeuweenhoek 73: 331-371.

Leys NM, Ryngaert A, Bastiaens L, et al. 2004. Occurrence and phylogenetic diversity of Sphingomonas strains in soils contaminated with polycyclic aromatic hydrocarbons. Appl Environ Microbiol 70: 1944-1955.

Macnaughton SJ, Stephen JR, Venosa AD, et al. 1999. Microbial population changes during bioremediation of an experimental oil spill. Appl Environ Microbiol 65: 3566-3574.

Maki H, Sasaki T, Harayama S. 2001. Photo-oxidation of biodegraded oil and toxicity of the photo-oxidized products. Chemosphere 44: 1145-1151.

Masoud W, Cesar LB, Jespersen L, Jakobsen M. 2004. Yeast involved in the fermentation of Coffea arabica in East Africa determined by genotyping and by direct denaturing gradient gel electrophoresis. Yeast 21: 549-556.

McGillivray AR, Sharis MP. 1993. Biotransformation of polycyclic aromatic hydrocarbons by yeasts isolation from coastal sediments. Appl Environ Microbiol 59: 1613-1618.

McKeague JA. 1981. Extractable cations. In Manual of Soil Sampling and Methods of Analysis. Canadian Soil Society Committee, prepared by Subcommittee on Methods of Analysis: Ottawa, Canada.

Meroth CB, Hammes WP, Hertel C. 2003. Identification and population dynamics of yeasts in sourdough fermentation processes by PCR-denaturing gradient gel electrophoresis. Appl Environ Microbiol 69: 7453-7461.

Meysami P, Baheri H. 2003. Pre-screening of fungi and bulking agents for contaminated soil bioremediation. Adv Environ Res 7: $881-887$.

Nielsen DS, Honholt S, Tano-Debrah K, Jespersen L. 2005. Yeast populations associated with Ghanaian cocoa fermentations analysed using denaturing gradient gel electrophoresis (DGGE). Yeast 22: 271-284.

Palittapongarnpim M, Pokethitiyook P, Upatham ES, Tangbanluekal L. 1998. Biodegradation of crude oil by soil microorganisms in thetropic. Biodegradation 9: 83-90.

Pan F, Yang Q, Zhang Y, Zhang S, Yang M. 2004. Biodegradation of polycyclic aromatic hydrocarbons by Pichia anomala. Biotechnol Lett 26: 803-806.

Prakitchaiwattana CJ, Fleet GH, Heard GM. 2004. Application and evaluation of denaturing gradient gel electrophoresis to analyse the yeast ecology of wine grapes FEMS Yeast Res 4: $865-877$.

Ringelberg DB, Talley JW, Perkins EJ, et al. 2001. Succession of phenotypic, genotypic, and metabolic community characteristics during in vitro bioslurry treatment of polycyclic aromatic hydrocarbon-contaminated sediments. Appl Environ Microbiol 67: $1542-1550$.

Romero MC, Cazau MC, Giorgieri S, Arambarri AM. 1998. Phenanthrene degradation by microorganisms isolated from a contaminated stream. Environ Pollut 101: 355-359.

Saponaro S, Bonomo L, Petruzzelli G, Romele L, Barbafieri M. 2002. Polycyclic aromatic hydrocarbons (PAHs) slurry phase biodegradation of a manufacturing gas plant (MGP) site aged soil. Water Air Soil Pollut 135: 219-236. 
Trindade PVO, Sobral LG, Rizzo ACL, Leite SGF, Soriano AU. 2005. Bioremediation of a weathered and a recently oil-contaminated soils from Brazil: a comparison study. Chemosphere 58: 515-522.

Villemur R, De 'Ziel E, Benachenhou A, et al. 2000. Two-liquidphase slurry bioreactors to enhance the degradation of highmolecular-weight polycyclic aromatic hydrocarbons in soil. Biotechnol Prog 16: 966-972.

Vinas M, Jordi Sabate J, Espuny MJ, Solanas AM. 2005. Bacterial community dynamics and polycyclic aromatic hydrocarbon degradation during bioremediation of heavily creosotecontaminated soil. Appl Environ Microbiol 71: 7008-7018.

Wilson SC, Jones KC. 1993. Bioremediation of soil contaminated with polynuclear aromatic hydrocarbons (PAHs). Environ Pollut 81: $229-249$.
Woodhull PM, Jerger DE. 1995. Temperature effects on kinetics and economics of slurry phase biological treatment. In Microbial Processes for Bioremediation, Hinchee R, Brockman F (eds). Battelle Press: Columbus, OH; 289-295.

Wu SP, Tao S, Zhang ZH, Lan T, Zuo Q. 2005. Distribution of particle-phase hydrocarbons, PAHs and OCPs in Tianjin, China. Atmosph Environ 39: 7420-7432.

Zinjardea SS, Panta AA. 2002. Hydrocarbon degraders from tropical marine environments. Marine Pollut Bull 44: $118-121$.

Zucchi M, Angiolini L, Borin S, et al. 2003. Response of bacterial community during bioremediation of an oil-polluted soil. J Appl Microbiol 94: 248-257. 